\title{
POTENSI KOMBINASI MEMANTIN DAN FITOMELATONIN DARI EKSTRAK BIJI BUNCIS (PHASEOLUS VULGARIS L) TERENKAPSULASI NANO-CHELATOR SEBAGAI INHIBITOR AGREGASI $\beta$-AMILOID DAN ANTIOKSIDAN : MODALITAS KURATIF MUTAKHIR PADA PENDERITA ALZHEIMER
}

\author{
Raafi Haidar Arrasyid, Endah Sari Ratna Kumala , Nisrina Hanifah Afnan \\ Program Studi Kedokteran, Fakultas Kedokteran, Universitas Islam Indonesia, Yogyakarta
}

\begin{abstract}
Alzheimer's is a disease that attacks the human central nervous system with signs of neurological atrophy and death in several regions of the brain. Data from the World Health Organization (WHO) in 2017 showed that the number of Alzheimer's sufferers reached 50 million people and in Indonesia it reached 1.2 million people. Current management has not been able to fully treat Alzheimer's and the high patient non-compliance with treatment has kept the Alzheimer's sufferer rate high. Knowing the combination of memantin and phytomelatonin encapsulated by nano-chelator as a curative therapy for Alzheimer's. The method used is literature study. The author analyzes related sources, the majority of which come from journals taken from PubMed, Science Direct, and Spinger. Memantin is a drug that has been used in the treatment of Alzheimer's by blocking NMDA receptors thus protecting nerve cells from inflammatory reactions and inhibiting the formation of $\beta$-Amilod aggregation. However, using one of these ingredients cannot show maximum results. Therefore, the authors combined memantine with phytomelatonin obtained from chickpeas (Phaseolus vulgaris $L$ ) with a role as an antioxidant and reduce $\beta$-amilod aggregation through a different pathway from memantin. To increase bioavailability, therapeutic accuracy, and the ability to penetrate the Blood-Brain Barrier (BBB) of these two materials, a nanochelator is used. Through the inhibitory effect of $\beta$-amilod aggregation formation and antioxidants from the combination of memantin and melatonin with nano-chelator encapsulation, it is hoped that Alzheimer's therapy can be more effective and efficient.
\end{abstract}

Keywords: Alzheimer's, combination, Memantine, Melatonine, and nano-chelator

\begin{abstract}
Abstrak
Alzheimer merupakan penyakit yang menyerang sistem saraf pusat manusia dengan tanda adanya atrofi dan kematian saraf pada beberapa regio di otak. Data dari World Health Orginazation (WHO) pada tahun 2017 menunjukkan angka penderita Alzheimer mencapai 50 juta orang dan di Indonesia mencapai 1,2 juta orang. Tatalaksana yang ada saat ini belum dapat mengobati Alzheimer secara menyeluruh dan tingginya ketidakpatuhan pasien dalam menjalani pengobatannya membuat angka penderita Alzheimer tetap tinggi. Mengetahui kombinasi memantin dan fitomelatonin yang terenkapsulasi nano-chelator sebagai terapi kuratif Alzheimer. Metode yang digunakan adalah studi literatur. Penulis menganalisis sumber-sumber terkait yang mayoritas berasal dari jurnal yang diambil dari PubMed, Science Direct, dan Spinger. Memantin merupakan obat yang telah dipakai dalam pengobatan Alzheimer dengan memblok reseptor NMDA sehingga melindungi sel saraf dari reaksi inflamasi dan menghambat pembentukan agregasi $\beta$-Amilod. Namun, penggunaan satu bahan tersebut tidak dapat menunjukkan hasil yang maksimal. Oleh karena itu, penulis mengkombinasikan memantine dengan fitomelatonin yang didapatkan dari buncis (Phaseolus vulgaris L) dengan peran sebagai antioksidan dan mengurangi agregasi $\beta$ Amilod melalui jalur yang berbeda dari memantin. Untuk meningkatkan bioavabilitas, ketepatan terapi, dan kemampuan menembus Blood-Brain Barrier (BBB) dari kedua bahan tersebut maka digunakanlah nano-chelator. Melalui efek penghambatan pembentukan agregasi $\beta$ - Amilod dan antioksidan dari kombinasi memantin dan melatonin dengan enkapsulasi nano- chelator diharapkan terapi Alzheimer dapat lebih efektif dan efisien.
\end{abstract}

Keywords: Alzheimer, combination, Memantine, Melatonine, and nano-chelator 


\section{PENDAHULUAN}

Alzheimer merupakan penyakit yang menyerang sistem saraf pusat manusia. Etiopatogenesis Alzheimer belum sepenuhnya diketehui, namun terdapat hipotesis etiologi Alzheimer terkait dengan adanya penumpukan $\beta$-Amiloid $(\mathrm{A} \beta)$ dan akumulasi protein tau di beberapa region otak. Tetapi hal ini masih menjadi perdebatan. 60-70\% angka penderita demensia. Alzheimer menyumbang sebanyak. Menurut data dari World Health Orginazation (WHO) pada tahun 2017, angka penderita alzheimer mencapai 50 juta orang dan terus meningkat setiap tahunnya. Di Indonesia sendiri angka penderita Alzheimer pada tahun 2016 mencapai 1.2 juta orang dengan rentang kasus usia tertinggi pada umur 75-84 tahun. Kerugian ekonomi yang akibat penanganan Alzheimer sebesar USD 1 triliun pada tahun 2018

Alzheimer merupakan penyakit neurodegeneratif yang ditandai dengan adanya atrofi dan kematian saraf pada beberapa regio di otak. Pengelompokkan Alzheimer berdasarkan fungsi otak dengan assessment Mini-Mental State Examination (MMSE) dapat dibedakan menjadi 4. Diawali dengan Mild Cognitive Impairment (MCI) lalu Mild AD, Moderate AD, dan Severe AD.

$\beta$-Amiloid merupakan hasil dari pembelahan Amiloid Precusor Protein (APP) secara prolitik dan tersusun dari 40 asam amino (A $\beta 140)$ hingga 42 asam amino (A $\beta 42)$, dimana $A \beta 42$ memiliki toksisitas yang lebih tinggi karena memiliki dua rantai yang lebih panjang. APP merupakan protein tipe 1 pada transmembran sel saraf yang bertanggung jawab dalam perkembangan saraf, penyaluran protein saraf, sebagai transduksi sinyal dan metabolisme lainnya. Pemrosesan APP dapat dilakukan dengan tiga protease , $\alpha, \beta, \gamma$, yang memberikan efek berbeda-beda pada hasilnya. Pembelahan APP oleh protease $\alpha$ dan $\beta$ menghasilkan fragmen APP yang larut, masing-masing yaitu APPs $\alpha$ atau APPs $\beta$ serta 99-residue C-terminal fragment (C99) yang terikat di membran plasma. Ketika APPs $\alpha$ dibelah menggunakan proteinase $\gamma$ akan menghasilkan p3 yang larut dan amyloid precursor protein intracellular domain (AICD) yang tetap berada pada transmembran. Berbeda dengan APPs $\beta$ yang dibelah menggunakan proteinase $\gamma$ akan menghasilkan $\beta$-Amiloid (A $\beta$ ) yang tidak larut dan akan membuat tumpukan serta AICD yang berada di transmembran. $\beta$ - Amiloid (A $\beta$ ) yang menumpuk akan membuat sinaps antar neuron terganggu hingga putus. $\beta$-Amiloid dapat menyebabkan kondisi yang toksik. Kondisi tesebut menyebabkan stress oksidatif yang ditandai dengan adanya peningkatan produksi reactive oxygen species (ROS) secara konstan sehingga dapat menyebabkan bocornya membran sel ketika transfer elektor dan mengurangi produksi Adenosin trifosfat (ATP). Selain itu ROS dapat menyebabkan mutasi pada DNA mitokondria (mtDNA) sehingga mempercepat terjadinya degenerasi neuron melalui jalur apoptosis.

Tatalaksana yang ada pada penderita Alzheimer dapat dibagi menjadi terapi nonfarmakologi dan farmakologi. Terapi non farmakologi yang ada merupakan aktifitas fisik untuk mengurangi proses peradangan dan melatih sistem kognitifnya dengan meningkatkan interaksi sosial. Sementara itu, penangangan secara farmakologis menggunakan obat-obatan yang bisa mengurangi dari plak $\beta$-amiloid, mengurangi inflamasi,dan memperbanyak kadar asetilkolin. Namun baik terapi farmakologi dan nonfarmakologi memiliki berbagai kekurangan. Dimana terapi farmakologi memiliki efek jangka pendek dan belum mampu menangani Alzheimer secara menyeluruh dan terkendala kepatuhan pasien dalam menjalani pengobatannya. 


\section{METODE}

Penulisan karya tulis ini menggunakan studi tinjauan pustaka yang berasal dari analisis dan sintesis berbagai referensi. Penulis memasukkan beberapa kata kunci kedalam mesin pencarian yakni Alzheimer, combination, melatonine, memantine,dan Nano-Chelator. Berdasarkan jurnal yang didapatkan, penulis memilih jurnal jenis full text, dan berkaitan dengan topik penulisan serta dilakukan penilaian selayaknya jurnal menggunakan metode STROBE. Jurnal yang didapatkan dipastikan memiliki tahun terbit maksimal 10 tahun terakhir, Referensi didapatkan dari jurnal yang dipublikasikan secara global yang dapat diakses melalui international library of medicine (Pubmed), Science Direct, dan Springer. Kemudian dilakukan analisa dan sintesa dari beberapa jurnal yang telah didapatkan sesuai dengan topik penulisan, kemudian disusunlah literature review ini.

\section{HASIL DAN PEMBAHASAN}

\section{Memantin Sebagai Terapi Alzheimer}

Memantin merupakan salah satu obat Alzheimer jenis antagonis reseptor NMDA (N-methyl-D- aspartate) yang telah diakui oleh Food and Drug Administration (FDA) Amerika Serikat dan diresepkan untuk meningkatkan daya ingat, kemampuan bahasa, dan melakukan tugas-tugas sederhana. Memantin digunakan untuk mengobati Alzheimer tingkat sedang hingga berat dengan dosis awal penggunaan adalah $5 \mathrm{mg}$ perhari, kemudian dosis ditingkatkan hingga $10 \mathrm{mg}$ dua kali sehari.

Glutamat berperan dalam pembelajaran dan memori dengan memicu reseptor NMDA yang akan mengontrol masuknya kalsium dalam sel saraf yang diperlukan untuk menciptakan lingkungan yang sesuai dalam menyimpan informasi. Namun, glutamate yang berlebih akan mengaktifkan reseptor NMDA diatas normal sehingga akan meningkatkan jumlah kalsium dalam sel saraf dan mengarah pada gangguan dan kematian sel. Kelebihan glutamate dapat dipicu adanya $\beta$-Amiloid baik secara langsung maupun melalui interaksi terhadap protein penahan post sinaptik. Memantin dapat melindungi sel dari kelebihan glutamat dengan memblokir reseptor NMDA. Selain memblokir reseptor NMDA, memantin telah terbukti mampu mengurangi kadar $A \beta$ yang larut maupun tidak larut. Hal ini dibuktikan pada penelitian yang dilakukan oleh Danysz et al (2012) melalui studi secara in vitro bahwa memantin dengan konsentrasi $1 \mu \mathrm{M}$ dapat pengobatannya. Metode $10 \mathrm{mg}$ dua kali sehari. menurunkan produksi $A \beta$.

Tetapi, penggunaan memantin belum memberikan efek yang maksimal pada penderita Alzheimer, sehingga kami sebagai penulis mengkombinasikan penggunaan memantin dengan fitomelatonin yang berasal dari ekstrak buncis (Phaseolus vulgaris L) yang dapat meningkatkan efek terapeutik pada penderita Alzheimer.

\section{Potensi Buncis (Phaseolus vulgaris L) sebagai sumber fitomelatonin}

Fitomelatonin merupakan kandungan yang ditemukan pada tumbuhan dari asam amino triptofan. Dari beberapa penelitian ditemukan bahwa fitomelatonin memiliki kadar tinggi pada tumbuhan yang dapat dikonsumsi. Keberadaan fitomelatonin pada tumbuhan berperan sebagai biostimulator dan regulator

Fitomelatonin ditemukan memiliki kadar diatas 10 ng/g jaringan pada tumbuhan yang dikonsumsi. Fitomelatonin memiliki konsentrasi tertinggi pada organ reproduksi tumbuhan yaitu biji dan kadar fitomelatonin meningkat sesuai dengan tingkat kematangan dari tanaman tersebut. Studi pada tikus meunjukkan peningkatan melatonin dan 6-sulfatoxymelatonin sebesar $16 \%$ dalam plasma setelah konsumsi buncis. Hasil pengukuran dengan High- performance liquid chromatography- 
mass spectrometry (HPLC-MS) bahwa kandungan fitomelatonin pada buncis sebesar $529 \mathrm{ng} / \mathrm{g}$. Buncis memiliki kapasitas antioksidan $56 \mu \mathrm{mol}$ of Trolox equivalent/g dry weight (DW).

\section{Potensi Melatonin Sabagai Pengobatan Alzheimer.}

Melatonin atau N-acetyl-5methoxytryptamine merupakan modulator biologis yang secara normal diproduksi oleh glandula pineal di dalam tubuh sebagai antioksidan yang kuat dan terapi. Melatonin mampu membantu penyembuhan beberapa penyakit seperti kanker dan AD. Melatonin mempunyai peran sebagai antiamiloidgenik, antioksidan, dan fotoprotektif pada sistem saraf pusat penderita AD. Melatonin dapat menargetkan mitokondria sel saraf pusat secara langsung. Beberapa efek yang dapat ditimbulkan adalah pengurangan volume dari mitokondria, peningkatan faktor biogenesis, menyeimbangkan membran potensial dan struktur mitokondria, stabilisasi dari mtDNA, dan menurunkan dari kadar $\mathrm{Ca}^{2+}$

Menurut penelitian Wang et al., pada tahun 2019, melatonin yang diberikan pada sel 20E2 sebagai model AD dengan kadar 0,1 uM, 1uM, dan $10 \mathrm{uM}$ selama 24 jam memiliki beberapa efek. Efek yang pertama dengan dosis $10 \mathrm{uM}$ adalah adanya viabilitas sel. Efek lain yang ditimbulkan adalah adanya peningkatan dari ekspresi protein TFAM (Trancription Factor A Mitocondria), NRF1 (Nuclear Respiratory Factor 1), NRF2 (Nuclear Respiratory Factor 2), dan PGC-1 $\alpha$ (Peroxisome Ploriferator- Activated Receptor $\gamma$ Coactivator 1- $\alpha$ ) yang berperan pada pengaturan biogenesis mitokondria dibandingkan tanpa intervensi melatonin.

Dengan pewarnaan JC-1 pada membran mitokondria yang telah diintervensi dengan melatonin terdapat peningkatan dari MMP (Mitochondrial Membrane Potential) dan adanya peningkatan $\mathrm{Na}+\mathrm{K}+$ ATPase dan aktifitas sitokrom $\mathrm{C}$ oksidase, produksi ATP, dan rasio dari mtDNA dibandingkan nDNA yang dapat diartikan adanya peningkatan fungsi mitokondria. Struktur mitokondria pada sel 20E2 mengalami adanya pembengkakan, hilangnya kristae, dan vakuol tetapi, setelah pemberian intervensi $1 \mathrm{uM}$ melatonin selama 24 jam mitokondria dapat mengalami perbaikan. Selain itu, pemberian melatonin dapat menurunkan CTF- $\beta$ ( $\beta$-Carboxyl-terminal fragment) dengan menginduksi penurunan BACE1 ( $\beta$-secretase 1) yang berperan dalam proses pembentukan $\beta$-Amiloid penderita $\mathrm{AD}$. 


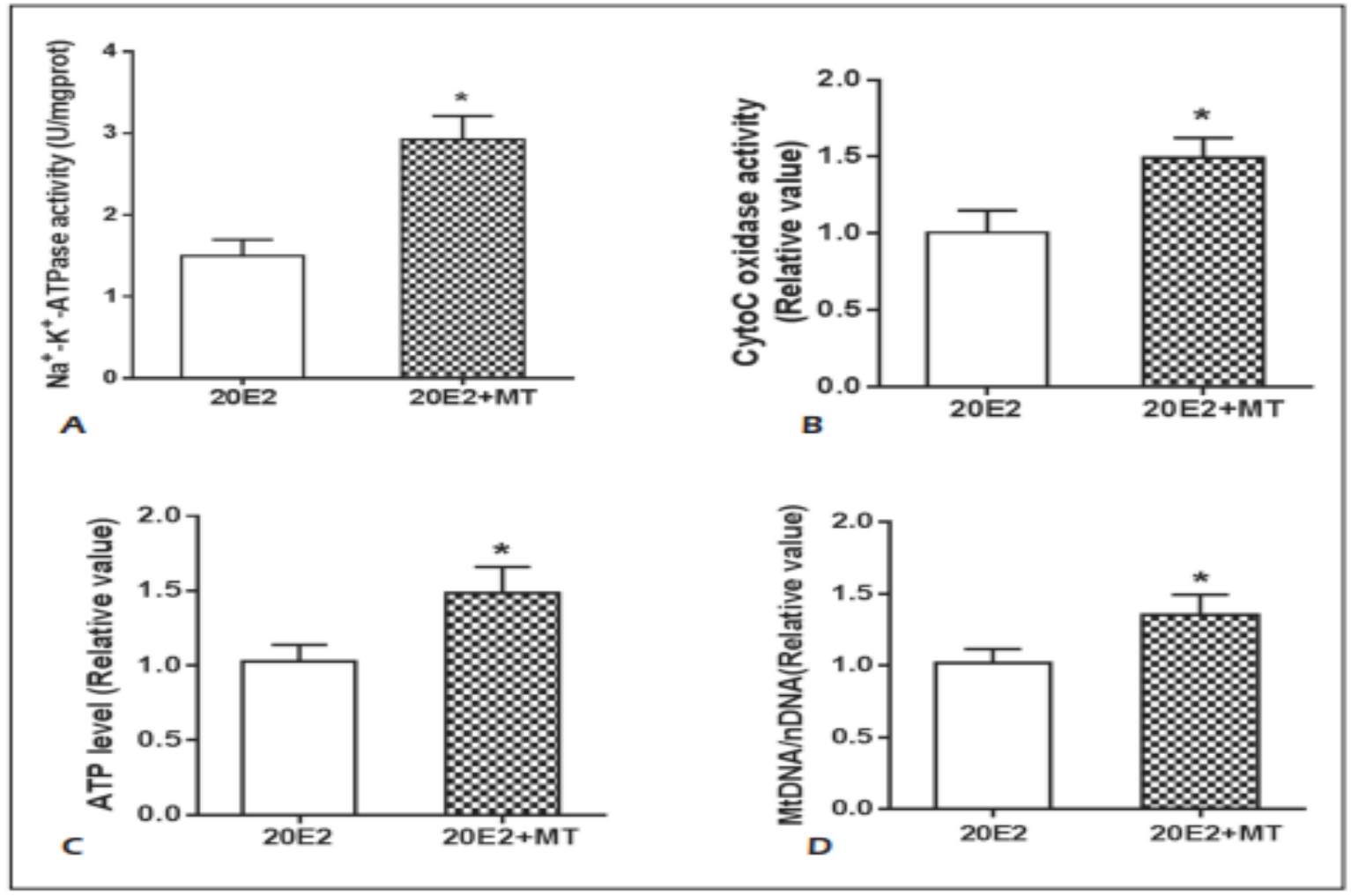

Gambar 1. Peneningkatan fungsi mitokondria setelah induksi melatonin.

\section{Kombinasi Memantin dengan Melatonin Sabagai Pengobatan Alzheimer.}

Seperti yang telah dijelaskan sebelumnya bahwa memantin merupakan obat yang telah digunkan dalam pengobatan Alzheimer dengan melindungi sel saraf dari sifat toksik glutamate. Sementara itu, melatonin merupakan antioksidan yang kuat dan diketahui bahwa dapat meningkatkan perkembangan kognitif pasien AD. Sehingga pemberian kombinasi memantin dengan melatonin mampu melindungi sel saraf dan mengurangi agregasi $\mathrm{A} \beta$ secara fektif daripada pemberian secara individu.

Hal ini dibuktikan oleh penelitian yang dilakukan oleh Jurgenso. M et al (2019) menggunakan model tikus 5xFAD yang menunjukkan pengurangan agregasi amyloid dibeberapa region otak seperti retrosplenal cortex $(\mathrm{p}<0.001)$, amigdala $(\mathrm{p}<0.001)$ dan subikulum $(\mathrm{p}<0.05)$ setelah diberikan kombinasi memantin sebanyak
$10 \mathrm{mg} / \mathrm{kg}$ dan melatonin sebanyak $6 \mathrm{mg} / \mathrm{kg}$. Memantin menghambat pembentukan agregat $A \beta$ yang diimediasi melalui jalur dependen dan independent reseptor NMDA. Selain itu, penelitian lain menunjukkan bahawa memantin mempengaruhi endositosis APP yang diperlukan dalam pembelahan $\beta$ - sekretase sehingga menurunkan produksi $A \beta$. Sementara itu, dalam studi kultur menunjukkan bahwa melatonin mampu menghambat pembentukan APP sehingga mencegah terbentuknya $A \beta$. Studi lain menyebutkan bahwa melatonin dapat berinteraksi dengan $A \beta-40$ dan $A \beta-42$ sehingga mengurangi kerusakan saraf. Melatonin juga diketahui mengatur beberapa protein kinase penting seperti faktor transkripsi NF- $\kappa B$, cyclin-dependent kinase 5 (CDK 5) dan mengaktifkan glikogen sintase kinase-3b (GSK- 3b) sehingga melemahkan hiperfosforilasi tau dan mengurangi akumulasi $\beta$ - Amiloid 
Tabel 1. Perbandingan secara statistik penurunan $\beta$ - Amiloid terhadap pemberian secara individu dan kombinasi

\begin{tabular}{lllll}
\hline Brain Area & $5 \mathrm{xFAD}$ & $\begin{array}{l}5 \mathrm{xFAD}+\text { melatonin } 6 \\
\mathrm{mg} / \mathrm{kg}\end{array}$ & $\begin{array}{l}5 \mathrm{xFAD}+\text { memantine } \\
10 \mathrm{mg} / \mathrm{kg}\end{array}$ & $\begin{array}{l}5 \mathrm{xFAD}+\text { memantine } \\
10 \mathrm{mg} / \mathrm{kg} \text { and melatonin } 6 \\
\mathrm{mg} / \mathrm{kg}\end{array}$ \\
\hline $\begin{array}{l}\text { Retrospenial } \\
\text { Cortex }\end{array}$ & $37.0 \pm 59$ & $31.1 \pm 3.5^{*}$ & $28.2 \pm 1.9^{* * *}$ & $15.6 \pm 2.2^{*}$ \\
\hline Amygdala & $27.8 \pm 2.1$ & $21.6 \pm 3.7^{* * *}$ & $23.0 \pm 2.2^{*}$ & $11.6 \pm 2.3^{* * * *}$ \\
\hline Subiculum & $70.1 \pm 6.4$ & $53.4 \pm 35^{*}$ & $66.8 \pm 5.7$ & $62.3 \pm 3.8$ \\
\hline
\end{tabular}

Selain dapat menurunkan produksi dan agregasi $\beta$-Amiloid, pemberian kombinasi memantin dan melatonin menunjukkan penurunakan reaksi inflamasi dengan adanya penurunan penanda inflamasi seperti microglial Iba-1 dan CD-45. Pemberian memantin sebanyak $10 \mathrm{mg} / \mathrm{kg}$ selama 13 hari mampu mengurangi kadar sitokin proinflamasi seperti tumor nekrosis faktor (TNF)- $\alpha$ dan Interleukin (IL-1 $\beta$ ) dan meningkatkan iNOS dan nNOS. Selain itu, melatonin memiliki efek sebagai antioksidan dengan menghambat NF- $\mathrm{KB}$ dan Cyclooxygenase (COX)-2, Menghambat aktivasi microglial sehingga menurunkan produksi sitokin proinflamasi, serta mengurangi IL-1 $\beta$ dan IL-6 dengan mengurangi agregrasi $A \beta$. (a)
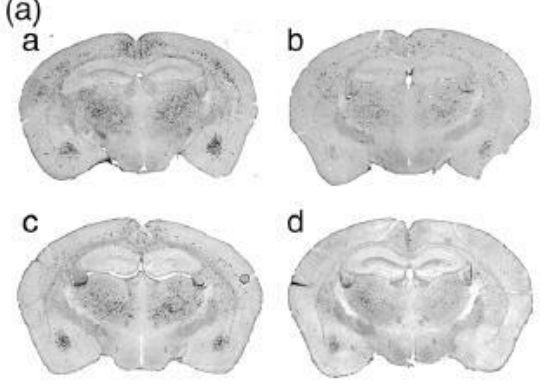

(b)
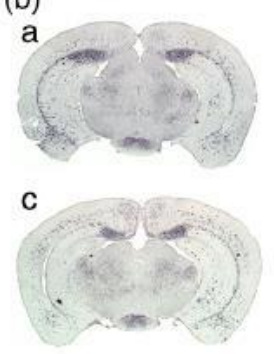

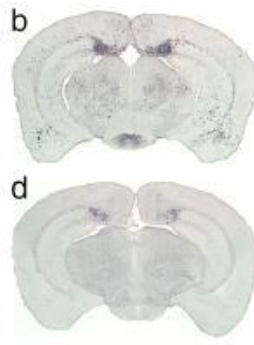

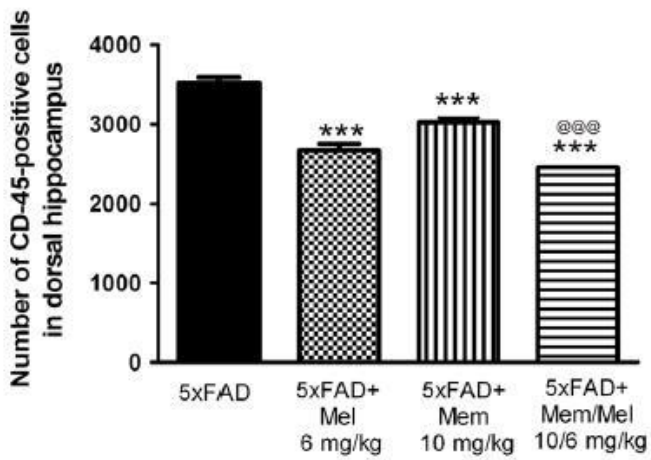

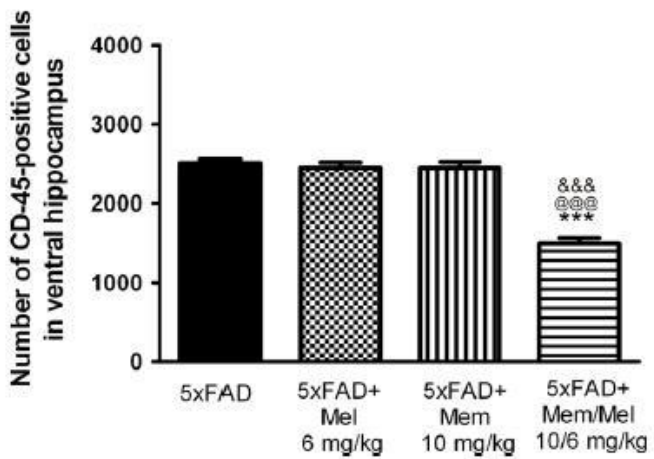

Gambar 2. Penurunan reaksi inflamasi ditandai dengan CD-45

\section{Potensi Nano-chelator sebagai delivery drugs}

Dalam tatalaksana penyakit Alzheimer ditemukan beberapa tantangan yaitu sulitnya menembus Blood-Brain Barrier
(BBB). BBB merupakan suatu pembatas antara otak dan disekitarnya. BBB memiliki lapisan monolayer yang melekat dengan tight junction, BBB memiliki kemampuan untuk memperbaiki kebocoran layer supaya tidak ada plasma yang memasuki dan 
mempengaruhi sistem saraf pusat (SSP). BBB mempunyai peran dalam menjaga homeostatis dengan mempengaruhi nutrisi dan imun dari SSP serta meregulasi interaksi molekul antara SSP dan darah. Hanya molekul protein berukuran 10$10.000 \mathrm{~nm}$ yang mampu menembus BBB.

Dalam merespon tantangan tersebut, penulis mengusulkan konjugasi nanopartikel- cehlator. Chelator di konjugasikan dengan nanopartikel karena mempunyai sifat untuk mengikat besi dan tembaga. Besi dan tembaga berperan dalam peningkatan stress oksidatif dan peningkatan sifat toksik $\beta$-Amiloid. Chelator dapat bekerja dengan tiga cara. Pertama, chelator mengurangi kandungan toksik yang ada pada $\beta$-Amiloid. Kedua, chelator dapat menginhibisi produk radikal bebas. Ketiga, chelator dapat mengurangi agregasi $\beta$-Amiloid yang disebabkan adanya stres oksidatif dari besi dan tembaga.

Nanopartikel dianggap mempunyai efisiensi dan dapat mengurangi sifat toksik dari obat yang ditujukan ke otak. Nanopartikel bekerja menyerupai low density lipoprotein (LDL) yang akan berikatan dengan reseptor LDL dan dapat menembus sel endotel otak yang dibantu transitosis transferin dalam transportnya. Nanopartikel juga dapat mengurangi toksisitas dari chelating yang ada.
Nanopartikel yang di kojugasikan dengan chealating besi mempunyai kemampuan yang lebih daripada yang tidak terkojugasi chealiting besi. Chealiting besi akan mengekspresikan kemampuan dalam mengurangi sifat toksik yang dimiliki $\beta$ Amiloid dan mencegah agregasi $\beta$ Amiloid.

Prototipe dari nanopartikel-terkojungasi chelator (Nano-N2PY) dibuat dengan cara yang kompleks. Karboksilat yang megaktifkan partikel nano di aktifkan oleh $\mathrm{N}$-cyclohexyl-N (2-morpholinoetyl) carboiimide metyl- ptoluensulfonate (CMC) yang kemudian direaksikan dengan chelator besi, 2-aminoetil MAEHP di Nmorpholino larutan buffer asam etana sulfonat (MES). Setelah proses sintetis dilakukan perbandingan serta mengecek konjugasi nanopartikel dan nanopartikelchelator (Nano-N2PY) di sampel kristal KCI IR menggunakan FT-IR Spectrophometer. Ikatan logam konjugat diteliti dengan besi dengan cara $\mathrm{Fe}(\mathrm{NO} 3)$ diinkubasikan dengan Nano-N2PY yang lalu dicuci dengan larutan EDTA (5Mm) dan diwarnai dengan metode Perl. Perubahan partikel yang awalnya biru menjadi putih menunjukan adanya besi. Pada perbesaran 37.000 ditemukan ferricferrocyanide adanya butiran pada permukaan nanopartikel.
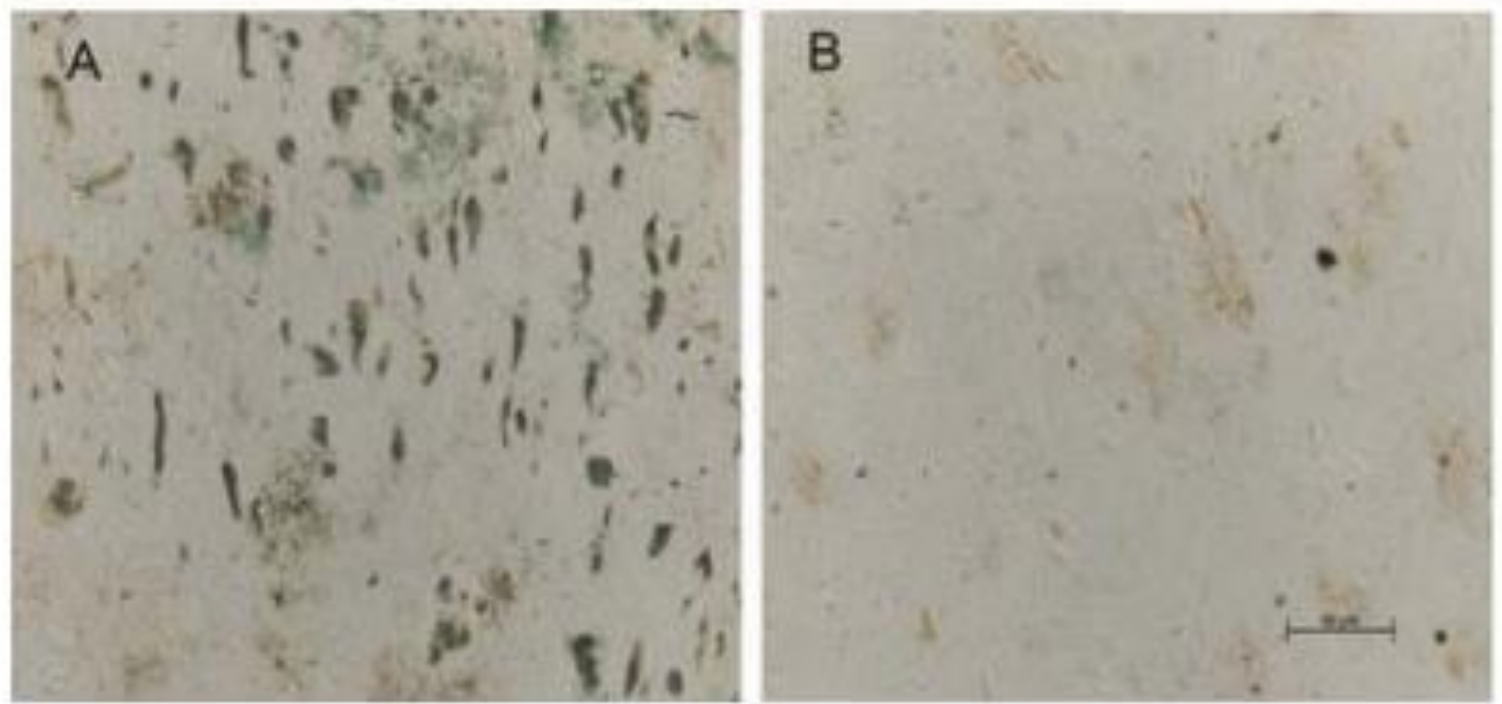
Gambar 3. (A). Kandungan Besi tanpa Nano-chelator di SSP (B) Kandungan besi dengan Nano-chelator menunjukkan adanya pengurangan

Eksperimen secara in vitro terhadap sel saraf kortikal dilakukan untuk menguji kemampuan Nano-N2PY dalam menginhibisi sifat toksik pada $\beta$-Amiloid. Sel (5000/well) di 96-well micro-plate dikultur pada media Dulbecco yang dimodifikasi Eagle dengan $1 \%$ serum bovine fetal pada suhu $37^{\circ} \mathrm{C}$ di atmosphere dengan kandungan $\mathrm{CO}_{2} 5 \%$. Konjugasi dan $\beta$-Amiloid ditambakan masing-masing dengan konsentrasi $2 \mu \mathrm{M}$ dan $1 \mu \mathrm{M}$. Kultur dibiarkan selama 3 hari, menggunakan Cytotoxity Detection Kit (LDH) ditemukan bahwa konjugasi melindungi sel saraf dari kandungan toksik $\beta$-Amiloid dibandingkan sel biasa yang diberi kandungan $\beta$-Amiloid. Dalam kerjanya Nano-N2PY tidak mempengaruhi proliferasi dari sel tersebut. Chelator yang dapat digunakan untuk menurunkan toksik dari $\beta$-Amiloid adalah desferrioxamine. Nano-N2PY merupakan derifat dari desferrioxamine (DFO) yang mempunyai afinitas tinggi terhadap besi, alumunium, tembaga, dan seng serta mengurangi kamampuan untuk berikatan dengan calsium dan magnesium. Dari sifat desferrioxamine, Nano- N2PY cocok dijadikan terapi untuk penderita Alzheimer yang menipiskan kandungan logam tanpa mempengaruhi ion-ion yang penting lainnya. DFO adalah satu-satunya chelating yang disetujui oleh Food and Drug Administration (FDA). Selain itu nanochelator mempunyai efek inhibisi agregasi dari agregasi $\beta$-amiloid dengan meningkatkan isoform pro-survival protein kinase (PKC) dengan efek penurunan translasi dari APP serta peningkatan dari factor neutropik dari BDNF (Brain Derivat Neutrophic Factor) dan GDNF (Glial Derivat Neutrophic Factor) yang berperan pada plastisitas sel saraf.

\section{KESIMPULAN}

Alzheimer merupakan penyakit yang menyerang sistem saraf pusat manusia dan ditandai dengan adanya atrofi dan kematian saraf pada beberapa regio di otak. Terdapat hipotesis etiologi Alzheimer terkait dengan adanya penumpukan $\beta$-Amiloid $(\mathrm{A} \beta)$ dan akumulasi protein tau di beberapa region otak, tetapi hal ini masih menjadi perdebatan. Tatalaksana yang ada pada saat ini belum dapat mengobati Alzheimer secara menyeluruh.

Sebagai upaya penanganan Alzheimer, diberikanlah kombinasi memantine dan fitomelatonin yang berasal dari buncis (Phaseolus vulgaris L) yang bekerjasama dalam menghambat pembentukan agregasi $\beta$-Amiloid dan reaksi inflamasi sehingga akan menurunkan akumulasi $\mathrm{A} \beta$, menghambat kematian sel, serta meningkatkan perkembangan kognitif pada penderita AD. Dalam meningkatkan bioavaibilitas obat, ketepatan terapi, dan dapat melewati Blood-Brain Barrier (BBB) maka digunakanlah Nano-chelator yang berperan sebagai enkapsulasi memantin dengan melatonin dan meningkatkan efek inhibitor agregasi $\beta$ - Amiloid.

\section{DAFTAR PUSTAKA}

1. Association A. 2012 Alzheimer ' $\mathrm{s}$ disease facts and figures. Alzheimer's Dement [Internet]. 2012;8(2):131-68. Available from: http://dx.doi.org/10.1016/j.jalz.2012.02. 001

2. Gaugler J, James B, Johnson T, Scholz K, Weuve J. 2016 Alzheimer's disease facts and figures. Alzheimer's Dement [Internet]. 2016;12(4):459- 509. Available from: http://dx.doi.org/10.1016/j.jalz.2015.02. 003

3. Iturria-Medina $\mathrm{Y}$, Sotero RC, Toussaint PJ, Mateos-Pérez JM, Evans AC. Early role of vascular dysregulation on late- 
onset Alzheimer's disease based on multifactorial data-driven analysis. Nat Commun. 2016;7(1).

4. World Health Organization (WHO). $2019 . \quad$ Dementia Fact Sheets.https://www.who.int/newsroom/fact-sheets/detail/dementia

5. Alzheimer's Association. 2019. Dementia Statistic. Alzheimer's Dementia 2019. https://www.alz.co.uk/research/statistic $\mathrm{s}$

6. Menkes RI. 2016. Demensia Usia Lansia. Kemenkes RI:Jakarta [Diakses 30 Juli 2020]

7. Alzheimer Indonesia. 2019. Statistik tentang

Demensia.https://alzi.or.id/statistiktentang- demensia/

8. Kumar A, Singh A, Ekavali. A review on Alzheimer's disease pathophysiology and its management: An update. Pharmacol Reports [Internet]. 2015;67(2):195-203. Available from: http://dx.doi.org/10.1016/j.pharep.2014. 09.004

9. Edmonds, E. C., McDonald, C. R., Marshall, A., Thomas, K. R., Eppig, J., Weigand, A. J., Bondi, M. W. (2019). Early versus late MCI: Improved MCI staging using a neuropsychological approach. Alzheimer's \& Dementia. doi:10.1016/j.jalz.2018.12.009

10. Zheng H, Koo EH. Biology and pathophysiology of the amyloid precursor protein. 2011;1(Figure 1):116.

11. Wang, X., Wang, W., Li, L., Perry, G., Lee, H., \& Zhu, X. (2014). Oxidative stress and mitochondrial dysfunction in Alzheimer's disease. Biochimica et Biophysica Acta

12. Wollen, KA. Alzheimer's Disease: The Pros and Cons of Pharmaceutical, Nutritional, Botanical, Ana Stimulatory Therapies, with a Discussion of Treatment Strategies from the Perspective of Patients and Practitioners. Alternative Medicine Review. 2010; 15(3):223-244.
13. Alzheimer assocation.2019. FDAapproved treatments for Alzheimer.

14. Danysz, W., \& Parsons, C. G. (2012). Alzheimer's disease, $\beta$-amyloid, glutamate, NMDA receptors and memantine - searching for the connections. British Journal of Pharmacology, 167(2), 324$352 . \quad$ doi:10.1111/j.14765381.2012.02057.x

15. B. Arnao, M.; Hernández-Ruiz, J. 2018. The Potential of Phytomelatonin as a Nutraceutical. Molecules 2018, 23, 238.

https://doi.org/10.3390/molecules23010 238

16. Salehi, B.; Sharopov, F.; Fokou, P.V.T.; Kobylinska, A.; Jonge, L.D.; Tadio, K.; Sharifi- Rad, J.; Posmyk, M.M.; Martorell, M.; Martins, N.; Iriti, M. Melatonin in Medicinal and Food Plants: Occurrence, Bioavailability, and Health Potential for Humans. Cells 2019, $8, \quad 681$ https://doi.org/10.3390/cells8070681

17. Arnao MB, Hernández-Ruiz J. Phytomelatonin, natural melatonin from plants as a novel dietary supplement: Sources, activities and world market. J Funct Foods 2018;48:37-42. https://doi.org/10.1016/j.jff.2018.06.02 3.

18. Wang, C. F., Song, C. Y., Wang, X., Huang, L. Y., Ding, M., Yang, H., Wang, P., Xu, L. L., Xie, Z. H., \& Bi, J. Z. (2019). Protective effects of melatonin on mitochondrial biogenesis and mitochondrial structure and function in the HEK293-APPswe cell model of Alzheimer's disease. European Review for Medical and Pharmacological Sciences, 23(8), 3542-3550. https://doi.org/10.26355/eurrev_201904 _ 17723

18. Jürgenson, M., Zharkovskaja, T., Noortoots, A., Morozova, M., Beniashvili, A., Zapolski, M., \& Zharkovsky, A. (2019). Effects of the drug combination memantine and melatonin on impaired memory and 
brain neuronal deficits in an amyloidpredominant mouse model of

Alzheimer's disease. Journal of Pharmacy and Pharmacology. doi:10.1111/jphp.13165

19. Liu, G., Men, P., Perry, G., \& Smith, M. A. (2009). Nanoparticle and Iron Chelators as a Potential Novel Alzheimer Therapy. Free Radicals and Antioxidant Protocols, 123- 144. doi:10.1007/978-1-60327-029-8_8

20. Li, X., Jankovic, J., \& Le, W. (2010). Iron chelation and neuroprotection in neurodegenerative diseases. Journal of Neural Transmission, 118(3), 473-477 